\title{
Caliber of lumbar puncture needle in preterm infants: few concerns
}

\author{
Tanushree Sahoo $^{1}$ (D) Krishna Mohan Gulla ${ }^{1}$
}

Received: 11 May 2020 / Revised: 30 May 2020 / Accepted: 2 June 2020 / Published online: 8 June 2020

(C) Springer-Verlag GmbH Germany, part of Springer Nature 2020

While applauding the authors' team for this interesting research [1], we would like to draw their attention towards the following issues.

1. The naming of study design is little bit puzzling: It is mentioned as prospective observational study. However, a new intervention has been introduced (using a smaller size lumbar puncture (LP) needle). Can it be mentioned as an interventional study?

2. Apart from needle size and experience of the physician performing LP, person assisting the procedure, level of sickness of the baby (e.g., need for mechanical ventilation, inotropic support, sclerema), level of sedation, and spinal level of needle insertion are some important factors which determine the success of LP in premature infants. Hence, these factors could have been considered in multivariate analysis.

3. Though authors have suggested $25-\mathrm{G}$ needle to reduce the incidence of traumatic LP, we feel "one size may not fit for all" and there should be a gestation-specific recommendation on the exact needle size.

4. There is no standardized cutoff for RBCs in cerebrospinal fluid (CSF) to define as traumatic LP [2-4]. Authors have chosen $500 \mathrm{RBC} / \mathrm{mm}^{3}$ as cutoff to define traumatic LP. Clinically, a lower cutoff of 200 to $300 \mathrm{RBCs} / \mathrm{mm}^{3}$ might be relevant. It would be better if they could have provided a break up category for $<500 \mathrm{RBC} / \mathrm{mm}^{3}$.

5. Similarly, in the absence of standard definition for $\mathrm{WBC}$ in CSF to diagnose meningitis in traumatic LP, CSF culture is the gold standard to define meningitis and it should be emphasized.

Communicated by Daniele De Luca

Tanushree Sahoo

tanushree_sony206@yahoo.co.in

1 Department of Pediatrics, Post Graduate Institute of Medical Education and Research (PGIMER), Chandigarh 160012, India
Finally, we agree with the authors that future adequately powered randomized controlled trials on this subject are needed before we can incorporate it in standard practice.

Authors' contributions TS contributed in collection of literature and drafted the manuscript. TS is the guarantor of final manuscript. KMG equally contributed in collection of literature and drafted the manuscript. All the authors approved the final version as submitted.

\section{Compliance with ethical standards}

Conflict of interest The authors declare that there is no competing interest.

Ethical clearance and consent Not applicable.

\section{References}

1. Flett T, Athalye-Jape G, Nathan E, Patole S (2020) Spinal needle size and traumatic neonatal lumbar puncture: an observational study (neo-LP). Eur J Pediatr 179(6):939-945

2. Shah KH, Richard KM, Nicholas S, Edlow JA (2003) Incidence of traumatic lumbar puncture. Acad Emerg Med 10(2):151-154

3. Lyons TW, Cruz AT, Freedman SB, Neuman MI, Balamuth F, Mistry RD, Mahajan P, Aronson PL, Thomson JE, Pruitt CM, Shah SS, Nigrovic LE, Kulik D, Okada PJ, Fleming AH, Arms JL, Garro AC, Uspal NG, Thompson AD, Ishimine PT, Alpern ER, Grether-Jones KL, Miller AS, Louie J, Schandower D, Curtis SJ, Schmidt SM, Bradin SA (2017) Interpretation of cerebrospinal fluid white blood cell counts in young infants with a traumatic lumbar puncture. Ann Emerg Med 69(5):622-631

4. Matettore A, Kollmann TR (2018) Traumatic neonatal lumbar punctures: experience at a large pediatric tertiary care center in Canada. Am J Perinatol 35(8):764-768

Publisher's note Springer Nature remains neutral with regard to jurisdictional claims in published maps and institutional affiliations. 